\title{
LITHUANIA'S SEARCH FOR INTERNATIONAL SUPPORT TO RESIST RUSSIAN AGGRESSION IN 1918
}

\author{
GEDIMINAS RUDIS
}

ABSTRACT The paper rejects a viewpoint prevalent among Lithuanian historians that the first government of the Republic of Lithuania, led by Augustinas Voldemaras, did not recognize the danger of Russia and was not concerned with the security of the state. Research shows that the government was fully conscious of the international situation of Lithuania and expected efficient diplomatic and military support from the Allies to counter Russian aggression. The orientation to the Allied powers was well-grounded, but too little attention was paid to the mobilization of the internal resources for the defence of the country. That was probably the most crucial drawback of the activity of Voldemaras' government. Such a conclusion can reasonably be drawn if one takes into account the fact that at that time the Allied powers had not yet defined their policy with respect to the Baltic states.

The situation of Lithuania at the end of 1918 and the start of 1919 is characterized unanimously by all historians as catastrophic. It was assessed similarly by many contemporary high officials, diplomats, and military of the country. At the beginning of January, as the Red Army approached Vilnius, the Lithuanian government hurriedly left for Kaunas, without even attempting to organize the defence of the capital. As there were no guarantees that it would be possible to be well entrenched in Kaunas, a plan for the evacuation of the government to Tilže (Tilsit in Lithuania Minor) was being prepared. The hopeless situation of that time was attested in many authentic contemporary documents. Thus, one of the first Lithuanian diplomats, a member of the State Council, Petras Klimas wrote in his diary on 15 January 1919:

The news has reached us that Kaunas will also be evacuated on 15 January, and the army, whose organization has just begun, will hardly be able to resist the Bolshevik Russians, enjoying the internal support (the German Soldatenrat has given a free hand to Russian agitators to act in the country). The railway line between Šiauliai and Kaišiadorys is not controlled any more, and communications between the Kaunas government and the country actually are disrupted. 
It is doubtful whether the conference to be convened on 19 January will take place. It looks like we have come to the end of the road. ${ }^{1}$

Nevertheless, the second congress of the Lithuanian state took place as it was planned (true, in Kaunas instead of Vilnius), though the delegates did not get any optimistic information. Asked about who defended Lithuania at that time, the prime minister answered very frankly: 'So far nobody does, because we have no forces. The Provisional Government has requested the Germans to keep away the Bolsheviks until we become stronger'.2

The hopeless situation of Lithuania late in 1918 and early in 1919 is unanimously stressed by everybody. Opinions of historians and politicians differ greatly only in the explanation of how that situation arose and whether everything had been done to prevent it. The explanation of the circumstances continued not only in the contemporary party struggles but also throughout the whole inter-war period, and the difference in viewpoints was most noticeable in the debates on the activity of the first Voldemaras government.

Petras Klimas, an able diplomat and a good historian, could be counted among the harshest critics of the Voldemaras government. In his view, in the face of military aggression from Soviet Russia 'the first cabinet of ministers did not develop the necessary reaction, it failed to catch the pulse of our convulsive life and meet the requirements, brought forward by society and the seriousness of the moment'. ${ }^{3}$ In his memoirs he was even more merciless:

The first steps of Voldemaras were strange. His declaration was professorially naive, mixed, and unpractical. He rejected the necessity to organize an army in the midst of various disturbances, all kinds of dangers and internal disorder. In his words, Lithuania seeks peace and nobody can attack peaceful nations. Under pressure he begins organizing the army, appointing an unknown Belorussian, Kondratovich, as minister of war, who absconds with the finances. Voldemaras himself prepares academically for his trip to the Paris Peace Conference. Meanwhile, after the disintegration of the German army, the Russians tread hard on its heels to take back their own country. ${ }^{4}$ Although less categorically than Klimas, Pranas Čepènas also noted a certain negligence and miscalculation in the activities of the

${ }^{1}$ P. Klimas, Dienoraštis 1915-1919 (Chicago, 1988), p. 303.

${ }^{2}$ Antroji Lietuvos Valstybès konferencija (Kaunas, 1919), p. 19.

${ }^{3}$ P. Klimas, Iš mano atsiminimu (Vilnius, 1990), p. 175.

${ }^{4}$ P. Klimas, Lietuvos diplomatineje tarnyboje 1919-1940 (Vilnius, 1991), p. 18; emphasis in original. 
first government: 'The Lithuanians, as well as the politicians of other re-established states, believed that the post-war territorial problems of various nations would be solved fairly at the Peace Conference' ${ }^{5}$ Neither did Čepenas support the unconditional accusation of Voldemaras' government concerning its delayed organization of the army, indicating that that was due to all sorts of obstructions on the part of the German occupational forces. ${ }^{6}$

In historical scholarship the viewpoints of Klimas and Čepenas predominate, and one could say, they have become traditional. Among the more original writers Alfred Erich Senn could be mentioned, in whose opinion even a more energetic activity of Voldemaras' government could not have achieved more in November 1918. He also stated that 'Lithuanian authors are biased in over-emphasizing the power of the Lithuanian army in 1919 and 1920 and in overdoing the accusation of Voldemaras'. 'Alas, this 'heretical' statement of Senn has not received proper attention. It was also overlooked by Vytautas Lesčius in his recent monograph ${ }^{8}$ in which Senn himself is not mentioned at all.

The controversy in the treatment of the activities of Voldemaras government encouraged the author of this paper to analyze the conception of the state security as it was conceived by the contemporary government and its responsibility for the fateful situation late in 1918 and early in 1919.

\section{The Prediction of the Threat of Russian Aggression}

The opinion that the government of Voldemaras and, in particular, the prime minister himself, generally did not foresee any great dangers for Lithuania is quite current in Lithuanian scholarship. This assumption is based mainly on the governmental declaration, proposed by Voldemaras in the State Council on 14 November 1918. It contained the following assertion: 'We are not at war with anyone of our neighbours and none of them - the Germans, Poles, Ukrainians, Russians and Latvians - have any grounds for attacking us. Therefore we do not need any great force to protect our borders'. ${ }^{9}$

Taking into consideration the fact that the 'frontiers' were far from being delimited at that time and, what was more important, that the founders of modern Lithuania were guided not by the principle of

${ }^{5}$ P. Čepènas, Naujuju laiku Lietuvos istorija (Chicago, 1986), t. 2, p. 293

${ }^{6}$ Ibid., p. 293.

${ }^{7}$ A. E. Senn, Lietuvos valstybès atkūrimas 1918-1920(Vilnius, 1992), p. 50

${ }^{8}$ V. Lesčius, Lietuvos kariuomenè 1918-1920 (Vilnius, 1992).

${ }^{9}$ Martynas Yčas, 'Lietuvos valstybès sudarymo etapai ir jos pirmieji žingsniai', Pirmasis nepriklausomos Lietuvos dešimtmetis, antrasis fotografuotinis leidimas (Kaunas, 1990), p. 75. 
national self-determination, but by a rather vague and complicated historical principle of 'ethnographic Lithuania', a statement like that could really appear over-optimistic. The region of Vilnius was the area where the interests of the Lithuanians, Poles and Belorussians clashed and served as a pretext for numerous conflicts. One should also not exaggerate this single statement and make far-reaching conclusions. It is common knowledge that governmental declarations should not be ignored, but they are very specific documents. Governments often resort to cheerful promises. After all, Voldemaras himself, having acknowledged many hardships in the creation of the state and a precarious internal situation at that time, drew a picture of a not too distant future:

Lithuania turns into large fields, gardens and lovely meadows with beautiful farm buildings scattered in the greenery. The farmsteads and towns are connected with roads smooth as a palm. The country is intersected by railways. Going to any place in Lithuania is easy and cheap. Occasionally you come across a factory. However, it is not marked by clouds of smoke from tall chimneys. It is driven by electricity, and only coming up closer you can hear a cheerful din of machinery. Around the factories, small and big towns are being built. There is hardly any difference among them - all are clean, pleasant and comfortable to live in. Everywhere there is electricity and sewerage. The difference is only seeming. Everywhere you see cheerful faces of healthy people. He who sees Lithuania will say: 'It is a country of labour and happiness'. ${ }^{10}$

Equally optimistically Voldemaras spoke about Lithuania's international situation, declaring peaceful co-existence with all her neighbours: 'Defending what belongs to us, we shall not lay claims to anybody else's property and therefore we are convinced that our relations with the neighbouring nations will be most friendly, particularly with those which will be as notoriously democratic as we shall'. ${ }^{11}$ Lithuania only introduced herself to the world as a peaceful country. However, when he stated that none of our her neighbours, including Russia, "has any reason to attack us', Voldemaras was not at all sure of that. When on 13 November 1918 Soviet Russia annulled the treaty of Brest-Litovsk as 'aggressive and unjust' and declared that all territorial concessions to Germany were no longer valid, he fully understood what all that meant for Lithuania. Before that, at the session of the State Council on 10 November he had stated: 'If the treaty of Brest is annulled, we become a part of Russia'. ${ }^{12}$

${ }^{10}$ Ibid., p. 74.

11 Ibid., p. 61.

${ }^{12}$ Valstybès Tarybos 19181110 posèdžio protokolas, Lietuvos Valstybès Tarybos protokolai 1917-1918 [hereafter LVTP] (Vilnius, 1991), p. 385. 
Voldemaras was not at all mistaken. Though the Russian government did not lay claims to Lithuania and other territories and declared the right of national self-determination, according to the Bolshevik class theory the right to self-determination belonged only to 'the working people'. Therefore, Lenin's government did not recognize the 'bourgeois' governments, established in Lithuania and in other countries, and endorsed the activities of the Communist parties which started to appeared in various regions. On 15 November 1918 Lenin recommended the Supreme Commander-in-Chief of the Red Army Ioakim Vacietis organize Lithuanian and Polish shock battalions and other troops. On the same day the Supreme Command-in-Chief of the Red Army re-organized the former Western defence region into the Western army, which started preparations for the occupation of the Baltic countries and Poland. In November Vincas Mickevičius-Kapsukas, Zigmas Aleksa-Angarietis and other Bolshevik Lithuanians of Russia were sent from Moscow to Vilnius with the task of establishing a Soviet government and declaring Lithuania a Soviet republic. By such actions Lenin hoped to deprive the Ukrainian, Lithuanian, Latvian and Estonian 'chauvinists' the chance of calling the Red Army's advent an act of occupation. In the 29 November telegram to Vacietis he indicated: 'In the absence of this condition, our troops would find themselves in a real predicament and the local population would not meet them as liberators' ${ }^{13}$

In passing, it must be noted that the Bolshevik Lithuanians of Moscow had not reached a unanimous decision on how that 'liberating' march of the Red Army should proceed. Some were eager to begin it without delay, others, on the contrary, were against hasty actions and wanted to have the situation correspondingly prepared in Lithuania in advance. Thus, on 10 November Rapolas Rasikas spoke at the sitting of the Central Bureau (Moscow) of the Lithuanian Section of the Russian Communist (Bolshevik) Party:

We are against independence and want Lithuania to be a part of the Russian Soviet Republic. We are forming soviets [councils], the Executive Committee and its departments there and we are establishing life on a new basis. We must carry out a coup d'etat there as soon as possible. We must muster a military force and go with it to Vilnius via Dvinsk (Daugavpils). ${ }^{14}$

Meanwhile Mickevičius-Kapsukas disagreed: 'According to Comrade Rasikas the most important task now is to send troops to Lithuania. However, that cannot be done as long as the revolution has

${ }^{13}$ Lenin to Vacietis, telegram of 29 November 1918, Dokumentai apie V. Lenino ryšius su Lietuvos revoliucinio judejjimo dalyviais (Vilnius, 1966), p. 62.

${ }^{14} R K P(b)$ Lietuviu sekciju Centro biuro protokolai $1918 \mathrm{~m}$. gegužès $28 \mathrm{~d}$. gruodżio $4 d$. Dokumentu rinkinys (Vilnius, 1987), p. 61. 
not won there'. ${ }^{15}$ These disputes came to an end abruptly when Lenin's government began hastening world revolution.

In this connection one curious incident is worth noting. In September 1918 Petras Klimas accidentally met Mickevičius-Kapsukas, who had come from Moscow, and talked him into having a conversation and exchange of information with several members of the State Council. In Klimas' words, it was quite an interesting encounter, but the talk was very odd, as if with a man from a different world:

Their views to Lithuanian independence" are Bolshevist: they are interested only in self-determination for the class of the workers and poorer peasants and then in the total socialist revolution throughout the world. They are expecting it to take place shortly in Germany, Austria, and Italy. The Lithuanian Commissariat ${ }^{16}$ is doing everything in its powers to move to Lithuania for the sake of the revolution. For them, revolution is an end in itself and the ultimate goal of their action. ${ }^{17}$

The Lithuanian government fully understood the contrivance of Soviet Russia, however it had to be more active in disclosing it. The passivity in this regard can be accounted for by the fact that the contemporary government consisted mostly of members belonging to the conservative Party of National Progress. Their viewpoints became evident in the discussion of the government declaration in the State Council on the ways of seeking international recognition for Lithuania. Česlovas Laurinavičius characterized that debate as a conflict between the conservatives and the radicals:

The conservatives (the Populists and partly Christian Democrats could be attributed to them) were of the opinion that the Lithuanian nation per se was too weak to acquire political independence and that the formation of the Lithuanian state and its consolidation would depend on its recognition by the great powers on the basis of bona fide or self-interest. The radicals (comprising the representatives of all Socialist parties) emphasized the will of the nation itself and its natural being in the process of the creation of the state. ${ }^{18}$

As a nationalist and no doubt a conservative, Voldemaras maintained: 'Recognition by the great powers is necessary for our

${ }^{15}$ Ibid., p. 56.

${ }^{16}$ The Commissariat for Lithuanian Affairs was established in Moscow in December 1917 with Mickevičius-Kapsukas as its head, it was a component of the People's Commissariat for Nationalities of the RFSSR.

${ }^{17}$ P. Klimas, Dienoraštis, p. 295.

${ }^{18}$ Č. Laurinavičius, 'Lietuvos valstybès pripažinimo problema ir jos sprendimas 1920 m. liepos 12 dienos sutartimi’, Proskyna, no. 1(10), 1991, p. 11. 
state to survive'. ${ }^{19}$ Jonas Vileišis, speaking on behalf of the Socialist Populist Faction, retorted:

The prime minister is not facing his task bravely. It seems to him that much depends on whether we shall be supported as a separate state by other states. In this respect there should not be any doubts. Once we have decided to be a free state and a nation as an entity and we have categorically declared that, nothing more could be added. There is no need to look at others - no sooner said than done. ${ }^{20}$

Certainly it was impossible 'not to look at others' at all, nevertheless, it must be acknowledged that the persistent reproaches to the government on the part of many members of the State Council for their excessive fear 'to go into the people' were not completely baseless. That became particularly evident in the organization of the army. Due to the lack of resources and in the face of all sorts of obstacles devised by the Germans, it was not feasible to achieve any tangible results. Therefore, not all the criticisms addressed to the government and, in particular to Voldemaras himself, in the State Council, in various political debates and even in the work of historians were rational. Certainly, one cannot but agree with Vileišis, who at the session of the State Council on 2 December 1918 accentuated that it was a great mistake to consider the army the only means of defence in such a situation when 'it was impossible to organize a corpus, when the Germans give with one hand and take back with the other'. Therefore, Vileišis urged Voldemaras: 'If you are afraid of the Bolsheviks, be genuine democrats, and you will have nothing to fear of. We shall not protect ourselves if we cannot go into the people open-hearted'. ${ }^{21}$

Voldemaras did not deny the importance of the support of broad sections of the population. 'We are looking for a dynamic force and we shall find it in the countryside', he stated at the session of the State Council on 10 November $1918 .{ }^{22}$ Nevertheless, it must be acknowledged that the search of the 'dynamic force' was possibly the most neglected field of the government's activity. That was the reason why Čepenas, generally reserved in his assessment of Voldemaras' government, nevertheless considered that in that extremely complicated political situation Voldemaras was not suitable for the post of the prime minister, since he did not believe in the unity of the nation and its determination to sacrifice itself ' in the crucial hour' ${ }^{23}$ Actually, any initiative 'from

${ }^{19}$ M. Yčas, Lietuvos dešimtmetis, p. 75.

${ }^{20}$ Ibid., p. 85.

${ }^{21}$ Valstybès Tarybos 19181202 posėdžio protokolas, LVTP, p. 429.

${ }^{22}$ Valstybès Tarybos 19181110 posèdžio protokolas, ibid., p. 386.

${ }^{23}$ P. Čepénas, Lietuvos istorija, pp. 371-372. 
below' caused Voldemaras' mistrust and sometimes even fear. The reproaches of the young officers (mainly of young ensigns and lieutenants) about the slow pace of army organization were treated by him as 'impermissible endless meetings' and the projects proposed by them as 'worth for nothing' - in general, he was of the opinion that there were no good organizers among Lithuanian officers. ${ }^{24} \mathrm{He}$ much more relied on Russian generals and colonels who happened to come to Lithuania, even though they did not realize that Lithuanian was the language of the Lithuanian army.

In a closed session of the State Council on 28 November 1918 Voldemaras characterized the situation of Lithuania with the following phrases: 'externally we are facing the danger of Bolshevism', 'the Germans cannot be trusted', 'relying on our forces we could not resist for a long time', etc. ${ }^{25}$ However, even under such circumstances he did not call for any energetic actions to mobilize all the available internal resources for the defence of the country. He was much more concerned with the prevention of the spread of Bolshevik propaganda in the Lithuanian army and required that every volunteer presented the necessary recommendations in order to avoid 'the infiltration of unreliable people'.

Luckily, the Bolsheviks also made quite a number of mistakes. For example, they did not take into account the expectations of the peasants to get the land of the estates. The contemporary Bishop of Vilnius Jurgis Matulaitis recorded rather many cases of increasing disillusionment with the Bolsheviks. On 10 January 1919, i.e., in less than a week after the Red Army had occupied Vilnius, he wrote:

The countryside people expected to get land from the Communists. However, seeing that the Bolsheviks kept the estates intact and were not going to divide land, the peasants grew cold to them and began to murmur, and the countryside became particularly dissatisfied with the Bolsheviks when they engaged in requisitioning foodstuffs here and there'. ${ }^{26}$

For the sake of comparison, it is worth remarking that afterwards Vincas Mickevičius-Kapsukas acknowledged that such a policy was a mistake, while Voldemaras never admitted having made any errors.

\section{Orientation towards the Entente}

By early November, when the government of Voldemaras was formed, the situation of Lithuania was still far from clear. That was unequivocally acknowledged by Voldemaras himself on 10 November:

\footnotetext{
${ }^{24}$ Valstybès Tarybos 19181128 posėdžio protokolas, LVTP, p. 413.

${ }^{25}$ Ibid., p. 411.

${ }^{26}$ J. Matulaitis, Užrašai (Vilnius, 1998), p. 129-130.
} 
We must make clear with what we are dealing. It is necessary to learn what is happening in Berlin. Possibly we have to apply for help from outside. Negotiating with the Germans we must tell them: if you do that and that for us, we shall supply you with provisions. So far our orientation in the general situation has been insufficient', ${ }^{27}$

Nevertheless, there was one thing which Voldemaras perceived quite distinctly, namely, that the future of Lithuania depended not on the relations with Germany, a loser in the war, but on those with the Entente. That was why the first step of the government was its attempt to apply to the Conference of the Allies at Spa for help against the Bolsheviks on 11 November 1918. Besides, that was one more indication that the government of Voldemaras was not at all sure about the future of Lithuania as was attested by that application.

In passing it should be noted that even up to the present an opinion, based on an article ${ }^{28}$ of Martynas Yčas, the minister of finance in Voldemaras' government, prevails, that a wireless telegram had been sent to Spa. Only Čepenas seems to have doubted that and indicated that the German occupational civilian administration refused to send that telegram. ${ }^{29}$ As a matter of fact, at the 28 November 1918 session of the State Council Voldemaras spoke that they failed to establish contact with the Entente: encoded telegrams were too cumbersome, wireless telegraph was not available, thus there remained only one possibility to act through the embassy in Berlin. ${ }^{30}$ Yčas himself complained to the Minister of Justice Petras Leonas in his letter from Berlin: 'Our telegram to Spa, which was to be sent from Vilnius, is still in Zimmerle's pocket. ${ }^{31}$

According to the armistice agreement, reached at Compiègne on 11 November 1918, the German army had to remain in the occupied countries in the East and could not withdraw from there until further instructions of the Allies. However, as there were on guarantees that that provision of the agreement would be fulfilled, Lithuanian politicians started intensively considering what should be done in such a case. Speaking on the same 11 of November at the session of the State Council and still unaware of the agreement at Compiègne, a member of the Council Aleksandras Stulginskis proposed three variants in case of a possible German withdrawal from Lithuania: to prepare for the

${ }^{27}$ Valstybès Tarybos 19181110 posėdžio protokolas, LVTP, p. 385.

${ }^{28}$ M. Yčas, Lietuvos dešimtmetis, p. 87.

${ }^{29}$ P. Čepénas, Lietuvos istorija, p. 292.

${ }^{30}$ Valstybès Tarybos 19181128 posèdžio protokolas, LVTP, p. 411.

${ }^{31}$ Leonas to Yčas, letter of 24 December 1918, LCVA, f. 923, ap. 1, b. 1295 , 1. 18. Ludwig Zimmerle was head of the German civilian administration in Lithuania. 
situation on their own, to invite the Allies or to ask the Germans to stay'. ${ }^{32}$ Voldemaras was of the opinion that it would be best to ask the Entente for support and he seemed to get it. The 25 November session of the government decided to send a delegation to Spa with the tasks of '(1) seeking diplomatic recognition of a sovereign and independent Lithuania with the capital Vilnius, and (2) asking to send troops as soon as possible in order to protect the country from anarchy'. ${ }^{33}$ The authorizations, extended to the delegation, indicated that financial and military support was needed because there was a danger of Bolshevism. ${ }^{34}$ The Lithuanian ambassador in Berlin, Jurgis Šiaulys, was also authorized to seek the aid of the Entente; hopes were placed on the activity of Lithuanian Americans in their pressure on the government of the USA to recognize Lithuania; attempts (unfortunately, unsuccessful) were made to get into contact with the British naval squadron, stationed at Liepāja, Latvia in December. All these endeavours did not result in any support of the Entente.

The main cause was the fact that the Entente powers had not yet formulated their policy concerning the Baltic countries. Though they often made verbal declarations about their willingness to reorganize Europe on the principles of justice and national selfdetermination, their intentions became blurred and vague as soon as they were faced with the problem of Russia's disintegration. In this respect only Poland and Finland were an exception. Neither did the Allies have a unanimous Eastern policy. The French strategists attempted to create an efficient barrier against Germany, and Poland was to play a decisive role. The British, however, were more concerned with the idea of a buffer between Germany and Russia. In their opinion, the national resistibility of the fringes could be a serious obstacle to the spread of Bolshevism. Correspondingly, the British were more interested in Lithuania due to the latter's geographical position. Lastly, the pragmatic economic interests of Britain could not be ignored either.

All these considerations were presented to Voldemaras when he visited the French and British ambassadors in Geneva in late October 1918. He was also received in the embassies of the USA and Italy. The Italians did not show any greater interest in Lithuania, while the Americans were curious about the situation in the country, however, without promising anything. ${ }^{35}$ Nevertheless, Voldemaras was

${ }^{32}$ Valstybès Tarybos 19181111 posèdžio protokolas, LVTP, p. 387.

${ }^{33}$ Vyriausybès 19181125 posèdžio protokolas, LCVA, f. 923, ap. 1, b. 9, 1. 8.

${ }^{34} 19181224$ igaliojimai delegacijai i Spa, ibid., b. 3, 1. 97.

${ }^{35}$ Raimundas Lopata, Lietuvos valstybingumo raida 1914-1918 metais (Vilnius, 1996), p. 173. 
convinced that the international recognition of Lithuania would not be a difficult issue. In the declaration of the government he indicated:

While in Switzerland I visited all the ambassadors of the Allied powers and I asked all of them about the recognition of our independence. Certainly, they could not give an immediate answer, since that depended on their governments, which they informed about my visit. The talks with them and many other details raise our hopes that Lithuania will be recognized by all states. ${ }^{36}$

This optimism of Voldemaras was grossly exaggerated. However, the establishment of diplomatic contacts with the Allied powers as a priority of Lithuanian foreign policy was productive. The second Lithuanian government, led by Mykolas Sleževičius, pursued a similar political course.

Voldemaras pinned his hopes on the Peace Conference, which, according to him, had to establish Lithuania's borders, and on the League of Nations as a guarantor of the independence of each nation. Nobody in the country even admitted the idea that Lithuania could not be invited to the Peace Conference - it went without saying. The Lithuanians overestimated the circumstance of the re-establishment of their former independence. In this respect they considered themselves different from the Latvians and the Estonians and did not care to establish contacts with them and to conduct a common political course of the Baltic states. When at the 3 December 1918 session of the State Council he was asked about what was being done for the rapprochement with Latvia and Estonia, Voldemaras answered arrogantly: 'The Latvians, having established their state later, should address us first' ${ }^{37}$ At that time nobody in Lithuania believed that Latvia and Estonia would achieve international recognition sooner than Lithuania. And when the things took a different course, Lithuanian false pride experienced a severe blow.

With the complicated situation of Lithuania continuing and no support coming from the Allied powers, it became increasingly clear that the country could rely only on its own forces and the Germans, who turned out not very reliable partners. In general, in Voldemaras' relations with the German civilian administration there was much tension, mutual mistrust and suspicion. Benevolent co-operation was out of question - at least much time was necessary for a change in the status of an occupier to that of a friendly partner. Besides, the Lithuanian government did its best to show the Entente that the reestablishment of the country had nothing to do with the Germans. On

${ }^{36}$ M. Yčas, Lietuvos dešimtmetis, p. 75.

${ }^{37}$ Valstybès Tarybos 19181203 posèdžio protokolas, LVTP, p. 437. 
the other hand, it could not boast about its self-dependency and independence from the Germans. Thus, in the first session of the government the Minister of Education, Jonas Yčas, complained that it was not normal that the finances, telegraph and telephone system were in the hands of the Germans, and the Lithuanian government could not have them at their disposal. That kind of situation could not be tolerated any longer. ${ }^{38}$ Voldemaras' government, however, did not manage to change the situation.

The withdrawal of the German divisions from the occupied eastern territories in late December 1918 was followed by the advance of the Red Army. The Lithuanian government, suspecting a secret German plot with the Bolsheviks, endeavoured to explain whether the German army was going to leave Lithuania without battle as well. Then it became clear that Voldemaras' government and the German civilian administration quite differently interpreted the armistice agreement of Compiègne. In his meeting with the Lithuanian representatives on 12 December $1918 \mathrm{~L}$. Zimmerle stated that according to the terms of the agreement the German army could leave Lithuania 'at any time'. Meanwhile, A. Voldemaras, the finance minister, M. Yčas, and the member of the State Council Simonas Rozenbaumas maintained that:

The Germans cannot leave Lithuania without its own army and without any defenders of its borders until the arrival of the Allied forces or until the Lithuanian government itself is able to keep order at home and defend the country from foreign invaders, in other words, until the government organizes its army, militia and local self-government. Russia has become a foreign power, and Lithuania, having declared her independence, has to protect herself from Russian invasion. The Germans cannot retreat from the borders. ${ }^{39}$

As no agreement was reached at this meeting, it was decided to apply to the Spa Commission for explanation and to appoint a commission of the representatives of the Lithuanian government and the German army 'to decide how long the German army is to stay in Lithuania'. ${ }^{40}$

Under such circumstances the situation of Lithuania became gravely critical. Namely in that manner it was characterized in the authorization for the delegation to Spa, signed by Voldemaras on 14 December $1918 .{ }^{41}$ In addition, eventually a deep internal crisis

\footnotetext{
${ }^{38}$ Vyriausybès 19181109 posèdžio protokolas, LCVA, f. 923, ap. 1, b. 9, 1. 1.

39 ‘Ar ilgai pasiliks vokiečiai Lietuvoje?', Lietuvos aidas, 191812 14, p. 2.

${ }^{40}$ Ibid.

${ }^{41}$ Igaliojimai delegacijai i Spa, LCVA, f. 923, ap. 1, b. 3, 1. 97.
} 
developed, when Voldemaras and M. Yčas left for Berlin for urgent financial aid and for the stay of the German forces in Vilnius. A day later the chairman of the State Council, Antanas Smetona, went abroad as well. From Berlin Voldemaras intended to go to Copenhagen and Paris to seek military support from the Entente. In his diplomatic passport, issued in the Lithuanian, German and French languages, it was stated that the Prime Minister and Minister of Foreign Affairs, Prof. A. Voldemaras, was sent by the government on a diplomatic mission to Great Britain, France, Italy, Belgium, the Netherlands, Sweden, Norway and the USA for three months. ${ }^{42}$ It is noteworthy that Germany was not mentioned among those states. Possibly it was a kind of a diplomatic trick in order to foul the trail and to make it easier to get entrance visas to the countries fighting against Germany.

The trip to Berlin was a success, since the German government agreed to issue a loan of 1,000,000 marks. That was very important, as it meant resources for the organization of the army. An agreement was also reached concerning the German government's order to the Commander of the Tenth Army, Erich von Falkenhayn, not to leave Vilnius. However, the latter refused to obey on the grounds of poor discipline among the soldiers and was going to leave Vilnius on 4 and 5 January. ${ }^{43}$ Therefore the two telegrams, which the State Council received from the embassy in Berlin on 29 December to the effect that it was decided in Berlin by no means not to give Vilnius up to the Bolsheviks, were not at all encouraging. The assurance that 'the State Council and the Government can quietly continue its work' ${ }^{44}$ sounded like a misunderstanding.

The situation was made still worse by the unexplained (even to the government and the State Council) and quite mysterious trips of Voldemaras and Smetona, which caused a good deal of confusion and panic. On 28 December the finance minister, Liudas Noreika, wrote to his old friend Smetona in Berlin, openly describing the mood in Lithuania: 'You are treated here by everybody as a deserter, and it is impossible to explain that this is not the case'. ${ }^{45}$ Fortunately, the crisis did not last long. The rest of Voldemaras' government resigned, and a new one, led by Mykolas Sleževičius, was formed. Historians

${ }^{42}$ A. Voldemaro diplomatinis pasas, LCVA, f. 923, ap. 1, b. 74, 1. 53.

${ }^{43}$ P. Čepènas, Lietuvos istorija, p. 299.

${ }^{44}$ Lietuvos neužims nauji okupantai', Lietuvos aidas, 191812 31, p. 1.

${ }^{45}$ Noreika to Smetona, letter of 28 December 1918, Naujas požiūris ì Lietuvos istorijq (Kaunas, 1989), p. 72. The publication of the letter was prepared by Algirdas Grigaravičius. 
often refer to this government as 'the government that saved Lithuania's independence'. ${ }^{46}$ Voldemaras, however, did not acknowledge his improper behaviour either at that time or later. Thus, in 1921 he wrote in his answer to a sharp criticism of the Christian Democrat leader Mykolas Krupavičius concerning his desertion in the face of the military aggression of Soviet Russia: 'To defend oneself on one's own, having neither an army nor weapons, would be a childish dream. There remained only the diplomatic way. Therefore I had to go to Berlin and further' ${ }^{47} \mathrm{He}$ even for some time did not recognize the government of Sleževičius and continued calling himself prime minister. He also did not obey Sleževičius' request to return to Lithuania without delay. Afterwards he presented his excuses by asserting that at the beginning of 1919 it was senseless to go back, as he could do more being abroad and seeking the support of the Entente. ${ }^{48}$ However, the results of his activity, in particular before his arrival in Paris, were rather insignificant. Having reached Copenhagen in January 1919 he had many contacts with the ambassadors of the Allied powers, but did not achieve any concrete results. He himself admitted: 'The general attitude towards us is favourable, but the Entente will not deliver any military support. There are no objections to sending volunteers to Lithuania, that, however, would cost us' ${ }^{49}$

There is no doubt that the diplomatic solution of Voldemaras was very important, nevertheless, it was not the only one. Sleževičius was no less concerned with the search of international support for Lithuania than Voldemaras was. In early January 1919 he wrote to the ambassador in Berlin Šaulys: 'Require the Entente powers to force them [the Germans] to defend Lithuania, demand they take back Vilnius, Daugpilis and Lyda. If the Germans do not do that, the whole of Lithuania will be occupied by the Bolsheviks'. ${ }^{50}$ Equally energetically Sleževičius was engaged in the mobilization of the internal resources for the defence of the country. He was convinced that nobody would help Lithuania if the country itself did not defend actively on its own. And that was what the government of Voldemaras lacked most of all.

${ }^{46}$ E.g., cf. Ričardas Čepas, 'Ministras pirmininkas Mykolas Sleževičius', Lietuvos Respublikos ministrai pirmininkai 1918-1940 (Vilnius, 1997), p. 78.

${ }^{47}$ A. Voldemaras, 'Keršių etika', Lietuvos balsas, $27-28192101$ 27-28.

${ }^{48}$ [A. Voldemaras], 'Truputis atsiminimu apie Lietuvos kūrimąsi', Lietuvos žinios, 19320607.

${ }^{49}$ Voldemaras to Šaulys, letter of 11 Jan. 1919, LCVA, f. 923, ap. 1, b. 40 , 1. 405-408.

${ }^{50}$ Sleževičius to Šaulys, undated letter, LCVA, f. 923 , ap. 1, b. 40, 1. 459. It was an answer to Šaulys' letter of 5 Jan. 1919. 


\section{Conclusions}

1. A more detailed analysis of the activity of the first Lithuanian government, led by Voldemaras, shows that rather frequent statements about the poor orientation of this government in the contemporary international situation were not quite accurate. The government evaluated the situation precisely, seeing the greatest danger for Lithuania in Soviet Russia.

2. The external factor was given priority in the conception of state security, and ultimate hopes were based on the diplomatic and military support of the Entente powers. The orientation to the Entente was rational, however, the government paid too little attention to the mobilization of the internal resources for the defence of the country. That was all the more necessary under the conditions when there were no guarantees for effective international aid.

\section{Author Details}

Doctor of Humanities Gediminas Rudis graduated from the University of Vilnius, at present he is a senior researcher of the Lithuanian Institute of History. His field of interests is the inter-war history of the Republic of Lithuania (1918-1940).

Address: Department of the History of the Republic of Lithuania, Lietuvos istorijos institutas, Kražių 5, LT-2001 Vilnius, Lithuania

Email: rudis.lii@pub.ost.lt

\section{LIETUVOS PASTANGOS GAUTI TARPTAUTINES PARAMOS RUSIJOS AGRESIJAI ATREMTI 1918 M. PABAIGOJE}

Santrauka

\section{GEDIMINAS RUDIS}

Straipsnyje paneigiama gana plačiai lietuvių istoriografijoje paplitusi nuomonè, esą pirmoji A. Voldemaro vadovaujama Lietuvos vyriausybè nepripažino iš $\mathrm{Ru}$ sijos kylančio pavojaus ir nesirūpino valstybès saugumu. Konstatuojama, jog vyriausybė gana tiksliai ịvertino Lietuvos tarptautinę padèti, o Rusijos karinei agresijai atremti tikejjosi sulaukti veiksmingos Antantès diplomatinès ir karinès paramos. Orientacija ị Antantę buvo pakankamai motyvuota, tačiau A. Voldemaro vyriausybė aiškiai per mažai rūpinosi vidinių resursų mobilizavimu gynybai. Tai buvo bene didžiausias A. Voldemaro vyriausybès veiklos minusas. Ypač turint galvoje, kad Antantès šalys dar nebuvo apsisprendusios dèl savo politikos Baltijos valstybiu atžvilgiu. 